\title{
A STUDY OF SOLO'S TOURISM PRODUCT POTENTIAL AS HALAL TOURISM DESTINATION IN INDONESIA
}

\author{
Amad Saeroji, Deria Adi Wijaya, dan Isnaini Wijaya Wardani \\ Faculty of Cultural Sciences, Universitas Sebelas Maret Surakarta \\ Email: amadsaeroji@gmail.com
}

\begin{abstract}
ABSTRAK
Solo atau secara administratif disebut Surakarta adalah sebuah kota budaya peninggalan Kerajaan Mataram. Sektor kepariwisataan dari jaman ke jaman menunjukan tren perkembangan baik dari sisi jenis wisata, daya tarik, dan amenitas. Salah satunya perkembangan mengarah pada potensi kepariwisataan halal. Tujuan dari penelitian ini adalah 1) mengkaji potensi wisata halal solo dengan pendekatan variabel 4A (atraksi, amenitas, aksesibilitas, dan kelembagaan) sebagai komponen utama; 2) mengkaji peluang Solo menjadi destinasi wisata halal Indonesia dalam memenuhi kriteria wisata halal yang ditetapkan GMTI (Global Moslem Tourism Index). Penelitian ini menggunakan metode kualitatif. Pengambilan data melalui teknik wawancara, observasi, kajian pustaka dan dokumentasi. Identifikasi potensi produk wisata halal adalah obyek subtantif sebagai dasar dalam mengkaji peluang pengembangan wisata. Data yang telah terkumpul dianalisis ke dalam empat variabel utama berdasarkan analisis Miles dan Hubberman untuk kemudian disajikan secara deskriptif. Hasil penelitian menunjukan bahwa potensi wisata halal Solo berdasarkan daya dukung produk wisata cukup tinggi. Keberadaan atraksi, amenitas, aksesibilitas dan kelembagaan wisata yang tersebar di seluruh penjuru kota dan daerah sekitar menjadi unsur penting perkembangan kepariwisataan halal. Peluang signifikan terutama pada ketersediaan amenitas berupa hotel dan restoran syariah dan atraksi yang berupa daya tarik syariah berbasis budaya masyarakat yang telah berkembang sejalan dengan pertumbuhan wisata halal dunia. Variabel pengembangan aksesibilitas dan kelembagaan masih menjadi pekerjaan rumah stakeholder pariwisata halal untuk memenuhi standar yang ditetapkan GMTI. Variabel yang menjadikan Solo layak dikunjungi sebagai destinasi wisata halal berada pada komponen atraksi dan amenitas sedangkan aksesibilitas serta kelembagaan masih perlu penanganan serius jika merujuk pada kebutuhan wisatawan muslim.
\end{abstract}

Kata Kunci: Destinasi; Peluang; Potensi; Produk Wisata; Wisata Halal.

\begin{abstract}
Solo or administratively called as Surakarta is a cultural heritage city of the Mataram Kingdom. Tourism of the city shows its development in terms of tourism variety, attractiveness, and amenity. One of the developments leads to halal tourism potentials. The aims of the study are 1) to identify the halal tourism potentials concerning on 4A approach (attraction, amenity, accessibility, and ancillary) as major components of tourism; 2) to examine the opportunities of halal tourism destination to meet the criteria set by GMTI (Global Muslim Travel Index). This study uses a qualitative method. Data were collected through interview, observation, literature review and documentation. The identification of halal tourism products leads to substantive object as basic for reviewing tourism development opportunities. The collected data was analyzed into four $4 \mathrm{~A}$ variables based on Miles and Hubberman analysis to be presented descriptively. The results showed that halal tourism potentials based on carrying capacity of tourism products is high. The existence of attractions, amenity, accessibility and tourism institution throughout city and the surrounding areas become an important element in the development of halal tourism. As a halal tourism
\end{abstract}


destination, Solo has significant opportunities, especially the availability of amenity in the form of sharia hotels, restaurants and community-based cultural attraction that has grown in line with growth of world's halal tourism. The accessibility and ancillary variables are still being homework for halal tourism stakeholders to meet the standards set by GMTI. The variables that make Solo feasible for halal destination are in attraction and amenity while accessibility and institutional sector still requires serious handling if referring to the needs of Muslim tourists.

Keywords: Destination; Halal Tourism; Potentials; Opportunity; Tourism Products.

\section{INTRODUCTION}

Motivation to travel based on religion or spiritual factor has become popular in recent times and occupied an important segment in international tourism. The significant growth of such travel has become a world trend in global tourism industry. The concept of religious tourism is actually not a new phenomenon in the development of world tourism. Religious tourism has long been an integral motif for the millions of people, such as Christians, Muslims, Hindu, and others, to travel with the purpose of pilgrimage to all destination of the world. But today, religious tourism becomes synonymous with the development of the world of modern tourism. Thus religion plays an important role especially in the development of religious tourism over centuries, including how religion can influence a person in using his spare time visiting sites mentioned in the Qur'an, the Bible, or other related sacred texts with the existence of elements of spirituality, such as the occurrence of miracles and the decline of revelation (Timothy and Olsen, 2006:9). According to Jaelani (2017:3) the term of religious tourism has developed along with the growth of Islamic economics globally, then becomes sharia (syariah), and recently a term shifts into halal tourism.

Islamic economics is an important part of today's global economy. There are seven sectors of Islamic economy that have increased significantly, namely culinary, Islamic finance, insurance industry, fashion, cosmetics, pharmacy, entertainment, and tourism. The whole sector carries a concept of halal in every product. There are several things that are becoming the motor of global Muslim market growth i.e. demographics of young and large Muslim market, rapid growth of Muslimmajority countries, Islamic values encourage the growth of Islamic business and lifestyles, growth of trade transactions between countries of the Organization of Islamic Conference (OIC), participation of multinational corporations, technology and connectivity am o ng countries (Ministry of Tourism Republ ic of Indonesia, 2015:1). In other hand, Indonesia is a country that has a diversity of religion, culture, heritage and traditions. In fact, Indonesia is also the country with the largest Muslim population in the world, it may have potential into a world halal tourism destination. Yet the development of halal tourism in In d onesia does not growth maximally. Not many travel agencies are likely to packing inbound trips with sharia tour packages, but there are many outbound travel such as the packaged of Umrah and Hajj.

Recently, the city of Solo has some hotels which based on sharia. It supports the needs of Moslem travelers with the facilities provided. The existence of amenities should be supported by the existence of attraction, accessibility and good governance and management. Thus, the this study will discuss the potential of attraction, accessibility, and ancillary related to halal tourism owned by the city of Solo which lead the development of halal tourism destination of Indonesia.

The concept of halal tourism originated from the phenomena of sharia tourism, Islamic tourism, Muslim-friendly tourism, halal holiday, family tourism, universal tourism (Nirwandar, 2016). The development of sharia tourism concept including the type of pilgrimage tourism or religious tourism (pilgrims tourism/spiritual tourism). Sofyan (2012:33) states that the definition of sharia tourism is broader than religious tourism which is a tour based on values of Islamic sharia. As advocated by World Tourism Organization (WTO), the consumers of sharia 
tourism are not only Muslims but also nonMuslims who want to enjoy local wisdom. Based on this understanding, the development of halal tourism concept is a tour activity that is not contrary to the values and ethics of sharia and related to the concept of halal and haram in the Islamic world.

The term of religious tourism can be defined as Muslim travel activities when heading to one place to another or when in a place outside of their normal residence for certain period of less than a year and to engage in activities with religious motivation. It should be noted that these activities should be in accordance with Islamic principles - halal (Zamani and Anderson, 2009). Religious tourism can serve as an activity that has motivation in accordance with Islamic principles. Such activities may include Hajj, Umrah, etc. Another form can be an expression of gratitude to Allah the Most Merciful and Omniscient and the recognition of His magnificence which can be observed anywhere in the past and now (Din, 1989).

Recently, the phenomenon of tourism is not only limited to certain types of pilgrimage/religious tourism, but developed into a new tourism form that is often called Islamic tourism or halal tourism, which is more universal like local wisdom, benefiting the community, elements of learning (education) (Ministry of Tourism Republic of Indonesia, 2015:2). In particular, halal tourism is a business activity in Islamic literature. The term halal refers to all that is commanded in religious teachings and becomes basic for Muslims' behavior according to the Qur'an or $\mathrm{Ha}$ dith of the Prophet (Jaelani, 2017:9). Law of Republic of Indonesia No. 33 Year 2014 states that halal products are the products that have been declared halal in accordance with Islamic Sharia. Thus, the Indonesian Ulama Council (MUI) states that Halal Certification is a fatwa or written law of the Indonesian Ulama Council which states that it is legal for a product, whether it is food, drink, medicine or cosmetics, in accordance with Islamic law.

In addition, Andriani, et.al. (2015) explains that halal tourism used by many peo- ple because of the characteristics of the products and service that are universal. Products and tourist services, attraction and tourism destinations in the sharia are the same with the products, services, attractions, and tourism destinations generally, do not conflict with the values and ethics of sharia. Then halal tourism is not limited to religious tour. As stated by Jaelani (2017:32) that halal tourism development is important because the benefits are not only felt by Moslem travelers. Halal tourism is open to everyone. The Ministry of Tourism will stir halal tourism in the hotel, restaurant and spa. Halal tourism can expect to make Indonesia as a friendly destination for Muslim travelers and requires standardization. Characteristics of halal tourism among other travel there tour packages covering Moslem-friendly travel destinations, as well as hotels, restaurants, and spa are halal.

Furthermore, as socialized by President of Islamic Nutrition Council of America that halal tourism is a new concept of tourism and not only for religious tourism such as Umrah and performing pilgrimage, but the understanding of halal tourism is tourism that serves holidays adjusted with style according to the needs and demands of Muslim travelers, certainly in this case the hotel offered carries principles of sharia and does not serve alcoholic beverages and separated spa facilities for men and women (Wuryasti, 2013).

The eleven criteria of halal tourism or sharia tourism issued by Crencentrating of Global Muslim Travel Index (Crencentrating, 2016):

1. Family Friendly Destinations

More than 50 percent of Muslim travelers travel with their families - a much higher percentage compared to other travel segments.

2. Muslim Tourist and Public Security

A safe and secure environment is the key to attracting tourists to their destination. Travel warnings issued on tourist destinations are the main indicators to ascertain general security situation of a country. The commemoration of this journey covers not 
only security and public security situation of a country but also other factors such as natural disasters and health epidemics.

3. Muslim Visitor Arrivals

One of the biggest indicators of destination popularity is the volume of Muslim visitor arrivals. The number of Muslim visitor arrivals has been extracted by applying Crescent Rating's proprietary Muslim arrivals calculation model to the overall visitor arrivals as reported by United Nations World Tourism Organization (UNWTO, 2011).

4. Dining Option and Halal Assurance

For Muslim tourists, halal food is a major concern when traveling. Given the complexity of the food industry, halal guarantees at food outlets make Muslim tourists feel comfortable choosing where to eat.

5. Access to Prayers Places

Performing prayers (Shalat) five times a day is one of five pillars of Islam. Shalat begins with wudhu--that is a certain way to cleanse before prayers. The prayer could be performed at any clean location, but most Muslims travelers would prefer a mosque or a designated place for prayers. Therefore the ease of access to prayer facilities in the temp of tourism will make Muslim tourists more comfortable. Non-OIC (Non-Organization of Islamic Cooperation) destination countries have actively set up prayer halls in places such as railway stations (Taiwan), shopping centers (Japan), tourist attractions (Singapore) and airports.

6. Airport Facilities

Airports provide various facilities and services that cater to the diverse needs of travelers from all over the world. It is very important an airport can meet their specific needs. The three most important facilities needed to serve Muslim tourists are the availability of prayer rooms, proper wudhu facilities and halal food/restaurants in both public and transit areas.

7. Accommodation Options

Providing accommodation options which cater to Muslim tourists is important. Having access to Halal food, prayer direction markings and water-friendly washrooms are some of the most important services that Muslims will look for to make their stay comfortable at hotels or other accommodation. Since most Muslim tourists travel with children and parents, having family-friendly accommodation will increase the attractiveness of a destination.

8. Muslim Travelers Needs Awareness and Outreach

This criteria looks at awareness of the Muslim travel market and its needs at the destination as well as specific outreach by the destination to this segment. This includes marketing campaigns by tourism bodies directly targeting this sector.

9. Convenience of Communication

Most Muslim travelers speak Arabic, Bahasa (Malaysia/Indonesia), English, French, Persian and Turkish. Therefore this criterion evaluates the proficiency in these languages for each destination. It is calculated based on the languages used by travelers from the top 30 Muslim travel outbound markets.

10. Air Connectivity

Air connectivity is an important consideration in planning a travel itinerary. It is a new criteria included in GMTI 2016. The scores are based on the level of air connectivity to the goal of top 30 outbound travel markets Muslims.

11. Visa Requirements

Visa requirements play a big role in choosing a destination for leisure. Thus, these criteria analyze the visa requirements of each destination for the top 30 Muslim travel outbound market.

According to Yoeti (1996: 160-162) tourism potential related to all things of tourism destination and become an attraction for tourists visiting destination. In addition Pendit (2003) explains that tourism potential is a variety of resources contained in a particular area that can be developed into a tourist attraction. Based on tourism potential definition, it can be concluded that tourism potential is a variety of resources owned by a place/region whether in the form of natural, 
cultural, and human potential which can be developed into a tourist attraction.

Tourism destination is an entity in a certain geographical area within which there are components of tourism and service products, as well as other supporting elements such as tourism industry actors, communities, and developer institutions that form a synergistic system in creating the motivation of visits and the totality of visits for the tourists (Pitana and Diarta, 2009). The tourism component is important in tourism activities. The tourism component is also the basis for forming a tourist destination. According to Cooper (1995) there are four components that must be owned by a tourist destination, namely: attraction, accessibility, amenity, and ancillary.

Attraction is a significant component in attracting tourists. An area can be a tourism destination if conditions support to be developed into a tourist attraction. The existence of tourist attraction is the reason and the motivation of tourists to visit a tourism destination. Amenity is all kinds of facilities and infrastructure needed by tourists during their stay in a tourist destination including hotels, restaurants, transportations and travel agencies. Accessibility is the most important thing in tourism activities. All kinds of transportation or transportation services become an important access in tourism. If an area has tourism potential, it must provide adequate accessibility so that the area can be visited. Ancillary related to things that support tourism, such as management agencies, tourist information, travel agent and stakeholders who play a role in tourism.

This study uses a qualitative method. Data collections were taken through interview techniques, observation, literature review and documentation. The identification of the potential of halal tourism products is a substantive object as the basis for reviewing tourism development opportunities. The collected data was analyzed into 4A variables based on Miles and Hubberman (1992) which used an interactive model for data analysis techniques including data collection, data reduction, data presentation, and conclusion or verification. Then the analysis is presented descriptively. The relationship between the concept of $4 \mathrm{~A}$ in tourism and the criteria of halal tourism set by GMTI are in the components of destination including accommodation, facilities, transportation, public security etc. which are explained in GMTI for details.

\section{DISCUSSION \\ Potential of Halal Tourism Products of Solo City}

\section{Tourist Attraction}

Tourist Attraction is all things that can be enjoyed by tourists in a tourist destination that includes the natural, cultural and man-made. Based on the observations made, Solo has a variety of objects and attractions that have good potential to be developed into a halal tourism destination. As for some of the halal tourism object consists of mosques, graves of Islamic figures, pesantren (Islamic boarding schools), museums, and shopping centers.

In the context of halal tourism, the needs of Muslim tourists will be places of worship to be the main attraction. Until now, Solo has several places of worship in the form of mosques that have great historical value with architecture inherent in line with JavaneseIslamic culture in the kingdom. As a heritage, some interesting mosques to visit are the Kasunanan Surakarta Great Mosque, AlWustho Mangkunegaran Mosque, Ki Ageng Henis Laweyan Mosque, Langgar Merdeka Mosque which is also located in Kampung Laweyan area, Al-Riyadh Mosque and Assegaf Mosque located in Pasar Kliwon District Surakarta.

Pilgrimage tourism is a religious-spiritual activity that puts the element of spiritualism with conducting journey to holy places such as a journey to the Islamic figures who contributed to the spread of Islam in the past. Solo has several popular graves as a pilgrimage destination e.g. Ki Ageng Henis graves located in front of Laweyan Mosque; Ki Gede Sala Graves in Keraton Kasunanan Surakarta complex; Astana Oetara Surakarta which is the grave of KGPAA Mangkunegara VI 
located in Nusukan Surakarta. In addition there are several graves of Habib and Kyai who play a role in the spread of Islam, such as Al-Riyadh Mosque Mausoleum in Pasar Kliwon District which is the graves of Habib Alwi Al-Habsyi, Habib Ahmad bin Alwi bin Ali Al-Habsyi, Habib Anis bin Alwi bin Ali Al-Habsyi; graves of Habib Abdul Qodir bin Abdurrahman Assegaf. Some graves of charismatic figures are K.H Umar Abdul Manan - a founder of Pondok Pesantren AlMuayyad Mangkuyudan Surakarta, buried in mosque complex Pondok Pesantren (Islamic Boarding School) Al-Muayyad; Grave of KH Samanhudi - a founder of Sarekat Dagang Islam Organisation located in Banaran Village; graves of KH Idr is Jamsaren and $\mathrm{KH}$ Ahmad Siroj in Makamhaji Laweyan complex - the founder of Pondok Pesantren (Islamic Boarding School) Jamsaran Surakarta.

Another halal tourist attraction is visiting pesantren (traditional Islamic boarding school) as an Islamic physical heritage and education system that still exist in the present. Some historic boarding schools in Solo, among others, include: Pondok Pesantren Jamsaren which is the oldest pesantren in Surakarta located in Jalan Veteran, Serengan District, Surakarta; Pondok Pesantren Al-Muayyad which is the oldest Al-Quran boarding school in Surakarta located at Jalan K.H. Samanhudi Mangkuyudan Laweyan Surakarta; and Pesantren Al-Mukmin Ngruki located precisely in Cemani Village, Sukoharjo Regency. This pesantren is implementing the combination of the traditional and modern education systems.

The next tourist attractions are museums. There are four museums worthy to be developed as halal tourist attractions in Solo, i.e. K.H. Samanhudi Museum at Laweyan, Keris Surakarta Museum at Sriwedari Stadium Complex, Radya Pustaka Museum as the oldest museum in Indonesia located in Taman Sriwedari Complex, and Batik Danar Hadi Museum at Jalan Slamet Riyadi, Surakarta. Moreover, the activities is more complete when being added with shopping tour in several places, such as: Kampung Arab at
Pasar Kliwon District which provides various goods and typical culinary products from the Middle East, Kampung Permata Jayengan, Solo Wholesale Center (PGS), Beteng Trade Center (BTC), and Klewer Market that sells varieties of clothing materials at a low price, Kampung Batik Laweyan and Kauman, Triwindu Antique Market (Ngarsopuro), and Souvenir Market located at the North Square of Surakarta Kasunanan Palace.

Furthermore some Islamic events are related to religious tourism. There are also some interesting Islamic events in the city. Some of the festivals which can be promoted as attractions include: Grebeg Mulud Nabi; Malem Selikuran; Grebeg Besar Masjid Ageng Kasunanan; Kirab Apem Sewu; and Haul Celebration of Habib Al-Habsy at Masjid Al-Riyadh in Pasar Kliwon District. However, these Islamic events need to be arranged in a calendar of event so the tourists especially Muslims can see the agenda of the city.

\section{Amenities}

The amenity is an essential element of a tourist destination. It includes facilities to enable the tourists to stay longer in enjoying or participating in the offered tourism attractions. According to the explanation from GMTI and Indonesia Ministry of Tourism, Sharia-based accommodation has become the Muslim tourists' needs in supporting halal tourism. Based on the observation in the field, there are two types of sharia accommodation concept, i.e. hotels and guesthouses.

In Solo City, there are eleven (11) sharia hotels, namely: Syariah Hotel Solo, Hotel Arini Syariah, Zaen Hotel Syariah, The Amrani Syariah Hotel, Hotel Aziza Solo, Assalaam Syariah Hotel Solo, Hotel Al-Madina, Multazam Hotel Solo, Cempaka Inn Syariah, Hotel D'Madinah, and Grand Amira Hotel Solo. Meanwhile, the city also has seven (7) sharia guesthouses, including Rumah Kita Syariah Guest House, Wisma Syariah Kartika, Rumah Teras Syariah Guest House, AlSalam Syariah Guest House, Wisma Syariah Yati, Wisma Syariah Atma Bhakti, and Grand Amanda Syariah Guest House. 
Table 1.

Sharia Accommodation in Solo City

\begin{tabular}{l|l|l|l}
\hline No & \multicolumn{1}{|c|}{ Name } & \multicolumn{1}{|c}{ Address } & \multicolumn{1}{c}{ Type } \\
\hline 1 & Syariah Hotel Solo & Jl. Adi Sucipto No.47, Gonilan, Kartasura & Hotel \\
2 & Hotel Arini Syariah & Jl. Slamet Riyadi 361, Penumping, Solo & Hotel \\
3 & Zaen Hotel Syariah & Jl. K.H. Samanhudi No.12, Purwosari, Laweyan, Solo & Hotel \\
4 & The Amrani Syariah Hotel & Jl. Brigjend. Slamet Riyadi No.534, Kerten, Laweyan, Solo & Hotel \\
5 & Hotel Aziza Solo & Jl. Kapten Mulyadi No.115, Kedung Lumbu, Ps. Kliwon, Solo & Hotel \\
6 & Assalaam Syariah Hotel & Jl. Garuda Mas, Pabelan, Kartasura & Hotel \\
7 & Hotel Al-Madina & Jl. Duwet Raya No.37, Pabelan, Kartasura & Hotel \\
8 & Multazam Hotel Solo & Jl. Garuda Mas No.4B, Pabelan, Kartasura & Hotel \\
9 & Cempaka Inn Syariah & Jl. Tiga Negeri No.18, Laweyan, Solo & Hotel \\
10 & Hotel D'Madinah & Jl. Apel III Gang Mangga XI, Jajar, Laweyan, Solo & Hotel \\
11 & Grand Amira Hotel & Jl. Veteran No.18, Ps. Kliwon, Solo & Guesthouse \\
12 & Rumah Kita Syariah & Purwosari, Laweyan, Surakarta & Guesthouse \\
13 & Wisma Syariah Kartika & Jl. Kapten Mulyadi No.140, Ps. Kliwon, Solo & Guesthouse \\
14 & Rumah Teras Syariah & Jl. Kapten Mulyadi, Ps. Kliwon, Solo & Guesthouse \\
15 & Al-Salam Syariah & Jl. Untung Suropati No.11, Kedung Lumbu, Ps. Kliwon, Solo & Guesthouse \\
16 & Wisma Syariah Yati & Jl. Rajawali No.5, Timuran, Banjarsari, Solo & Guesthouse \\
17 & Wisma Syariah Atma Bhakti & Jl. Duku VII No.12, Jajar, Laweyan, Solo & Guesthouse \\
18 & Grand Amanda Syariah & Telukan, Grogol, Solobaru &
\end{tabular}

Source: Surakarta in Figures, BPS Surakarta, 2017

The next component of amenities in the city of Solo is dining and drinking places, as presented in the following table.

Table 2.

Foods and Beverages

\begin{tabular}{|c|c|c|c|}
\hline No & Name & Type of F\&B & Address \\
\hline 1 & Soto Gading & Soto & Jl. Brigjen Sudiarto, Ps.Kliwon, Solo \\
\hline 2 & Adem Ayem & Gudeg Solo & Jl. Slamet Riyadi No.342, Penumping, Solo \\
\hline 3 & R.M. Timlo Solo & Timlo & Jl. Jend.Urip Sumoharjo No.94,Jebres, Solo \\
\hline 4 & Timlo Sastro & Timlo & J1. Kapt. Mulyadi No.8, Sudiroprajan, Solo \\
\hline 5 & Bebek Goreng H. Slamet (Asli) & Duck Cuisine & J1. Slamet Riyadi No.618, Jajar, Solo \\
\hline 6 & Restoran Omah Sinten & International & J1. Diponegoro No.45, Keprabon, Solo \\
\hline 7 & Sate Kambing Mbok Galak & Lamb Satai & Jl. Ki Mangun Sarkoro No.112, Sumber, Solo \\
\hline 8 & R.M. Pecel Solo & Pecel & J1. Dr. Soepomo No.55, Turisari, Solo \\
\hline 9 & Selat Mbak Lies & Selat Solo & Jl. Veteran, Gang II No. 42, Serengan, Solo \\
\hline 10 & Bakso Alex & Meat Ball & Jl. Yosodipuro No.12B, Ketelan, Solo \\
\hline 11 & Soto Triwindu & Soto & Jl. Teuku Umar, Keprabon, Solo \\
\hline 12 & Sate Kambing Bu Hj. Bejo & Lamb Satai & Jl. Sungai Sebakung, Kedung Lumbu, Solo. \\
\hline 13 & Tengkleng Mbak Dyah & Tengkleng Kambing & Jl. Tanjunganom, Grogol, Solobaru \\
\hline 14 & Bakso Kadipolo Solo & Meat Ball & J1. Ronggowarsito No.163, Timuran, Solo \\
\hline 15 & R.M. Selat Vien's Solo & Selat Solo & Jl. Hasanudin No.99, Punggawan, Solo \\
\hline 16 & Sate Kambing "ASLI” Tambak Segaran & Lamb Satai & J1. Sutan Syahrir No.149, Setabelan, Solo \\
\hline 17 & Nasi Liwet Bu Wongso Lemu & Nasi Liwet & Jl. Teuku Umar, Keprabon, Solo \\
\hline 18 & Sate Kere Yu Rebi & Tempe Gembus Satai & J1. Kebangkitan Nasional Kios 1, Sriwedari, Solo \\
\hline 19 & Bakmi Djowo Mbah Mangoen & Javanese Noodle & Jl. Kenanga, No. 23, Purwosari, Solo \\
\hline 20 & R.M. Kusuma Sari Solo & International & Jl. Slamet Riyadi No.111, Kemlayan, Solo \\
\hline 21 & Soga Resto & International & Jl. Slamet Riyadi No.261, Sriwedari, Solo \\
\hline 22 & Restoran Diamond & International & Jl. Slamet Riyadi No.392, Purwosari, Solo \\
\hline 23 & Restoran Goela Klapa & International & Jl. Menteri Supeno No.3A, Manahan, Solo \\
\hline
\end{tabular}


Lanjutan Tabel 2

\begin{tabular}{l|l|l|l}
\hline No & \multicolumn{1}{|c|}{ Name } & \multicolumn{1}{|c}{ Type of F\&B } & \multicolumn{1}{c}{ Address } \\
\hline 24 & Cafedangan Tiga Tjeret & Typical Foods & Jl. Ronggowarsito No.97, Keprabon, Solo \\
25 & Serabi Notosuman & Serabi Solo & Jl. Mr. Moh. Yamin No.28, Jayengan, Solo \\
26 & Toko Roti Orion “Mandarijn” & Mandarijn Cake & Jl. Jend. Urip Sumoharjo No.80, Solo \\
27 & New Ice Cream Tentrem & Ice Cream & Jl. Slamet Riyadi No.132, Keprabon, Solo \\
28 & Depot Es Nini Thowog & Iced Beverage & Jl. Arifin No.59, Kepatihan Wetan, Solo \\
30 & Susu Segar Shi Jack & Fresh Milk & Jl. Dr. Muwardi, Kota Barat, Solo \\
31 & Susu Segar Shi Jack & Fresh Milk & Jl. Kapten Mulyadi, Loji Wetan, Solo \\
\hline
\end{tabular}

Source: Surakarta in Figures, BPS Surakarta, 2016

\section{Accessibility}

The transport accessibility plays an important role in the tourism development in an area or region. Geographically, the location of Solo City is very strategic as a junction point of the regional transportation system besides its popularity as a tourist destination. The development of the transportation system in the city has increased significantly along with the operation of public transportation and tourist transportation. The public transportation includes Prambanan Ekspres Train connecting Solo - Klaten - Yogyakarta - Kutoarjo; Batara Kresna Train connecting Solo - Sukoharjo - Wonogiri; and Batik Solo Trans which is tourist buses operating within the city. In addition, to support the tourist transportation, the city also offers Sightseeing Buses named "Werkudara" and Tourist Trains named "Sepur Kluthuk Jaladara". The Solo transportation system is also equipped with the transportation infrastructures, including four train stations (Purwosari Station, Solo Balapan Station, Jebres Station, and Solo Kota Station), one Type A Bus Terminal (Tirtonadi Bus Terminal), and one International Airport (Adi Soemarmo Airport).

The development of halal tourism in Solo is also supported by the opening of Solo - Jeddah flight route by Garuda Indonesia Airlines. The route operates twice a week, i.e. Tuesday and Thursday. For the Solo - Jeddah route, the departure time is $10.30 \mathrm{am}$ and the arrival time (in Jeddah) is 18.10 local time. Similarly, the Jeddah - Solo route is served on the same day from which the departure time is 21.10 Jeddah time and the arrival time is $11.00 \mathrm{am}$. The aircraft is Airbus 333 with a capacity of 362 passengers. In addition, Lion Air also serves the same flight route three times a week (Monday, Tuesday, and Saturday) using Boeing 737 MAX 8 with a capacity of 180 passengers.

\section{Ancillary Services}

The government's support is very beneficial to the effort to optimize halal tourism in Solo. The Solo City Government through its Tourism Office stated that in the effort of implementing the strategy for optimizing the halal tourism, the government has provided a very positive response as stated in the policies as follows: (1) the government seeks to build and prepare facilities and infrastructure to satisfy the needs of the Muslim travellers so they have no difficulty in performing worship such as providing prayer rooms or small mosques in tourism spots; (2) the government has socialized the concept of halal tourism that must be understood by businessmen/entrepreneurs engaged in tourism services and encourages the tourism industry entrepreneurs to have a halal certificate from MUI; (3) the government encourages the issuance of regulations on the halal tourism destination by increasing the number of halal-certified products (from MUI) such as typical culinary products and city souvenirs; 4) as an effort to increase the number of halal tourists, the government has issued regulations that support halal tourism such as Sharia Hotel Management Regulations, MUI's Halal Certification Regulations. However, there is a problem in acquisition cost for halal certificate mainly for small and medium enterprises since it needs sufficient funding (Surakarta Tourism Office, 2018). 


\section{The Solo's Opportunity as a Halal Tourism Destination in Indonesia}

The Muslim travelers' needs for a halal tourism destination are the key for an area to develop its tourism sector through a touristdemand approach. Based on the discussion on the four components of halal tourism products, Solo has a great opportunity to serve as a halal tourism destination of Indonesia. The GMTI criteria, which are the world benchmark in the development of halal tourism, can certainly be pursued by regions or cities that have such potential. The main components of the city of solo as a halal tourism destination are divided into attractions, amenities, accessibility and ancillary services that support the development of tourism of the city.

The existing tourist attractions in Solo can be served as a pulling factor to attract the Muslim travelers. As a cultural city with a royal heritage from the Islamic Mataram Kingdom, the palace's traditions and rituals have become part of the Solonese culture. Before the concept of halal tourism emerged, Solo has had a regular tourism agenda and been visited by many tourists, both local and foreign, especially Muslims. This is a typical opportunity which, of course, must be maintained and improved in term of the quality.

The accommodation in response to the needs of Muslim travelers is readily available in all corners of the city. Sharia-based hotels and restaurants are also present to satisfy the wishes of tourists adjacent to the tourism objects and attractions. Until now, there are 18 sharia-based hotels and guest houses located in the city of Solo and surrounding areas. This number may still increase along with the trend of the development of halal tourism in Indonesia and the increase of Muslim travelers' visit in the coming time. In addition, the Muslim travelers' needs for halal food and beverage are already available both in sharia hotels and restaurants that are certified halal by MUI. As shown in Table 2, as many as 31 halal eating places are ready to serve the Muslim tourists. Thus, the city of Solo has met the standard requirements as proposed by GMTI on the component of amenities so the city has an opportunity to be developed as a halal tourism destination in Indonesia.

One of the factors influencing the success of tourist visit is accessibility, either local, national, or international with inbound and outbound travel. Accessibility components in the city of Solo can be considered affordable given the availability of a bus terminal, four train stations, and an international airport as well as adequate local transport. However, the frequency of flights both in and out of the airport needs to be increased along with the development of attractions and amenities in the city. It is not surprising that the affordability of a city becomes the determinant of the success of tourist visit, especially those from Muslim countries (e.g. the Middle East).

Another important component of the tourism system lies in the ancillary services or tourism management. Without an organizing institution, regional tourism would be difficult to realize a synergy between tourism components, especially in the case of halal tourism as a new tourism concept, which certainly requires established planning, implementation, and evaluation for the success of the destination management. The role of tourism stakeholders (such as government, travel agencies, tourism organizations, professional associations, academics, etc.) in regulating a halal tourism destination is essential since, without an integrated management, the components prepared to capture the halal tourism opportunity cannot work together well. Institutions regulate the policies on attractions, amenities, and accessibility as shown in the following Figure.

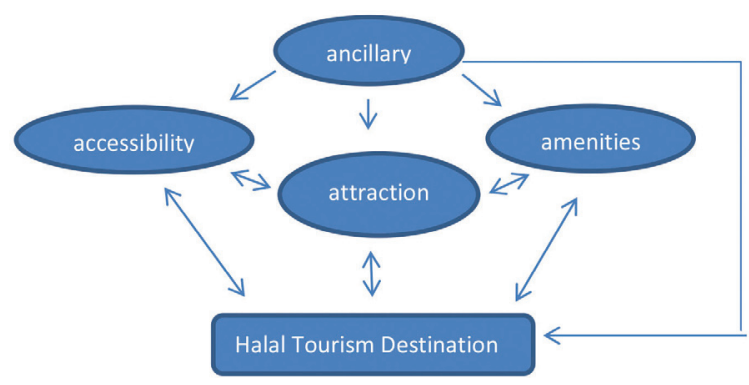

Figure 1.

Halal Tourism Products in Solo City Source of image: Analysis, 2018 


\section{CONCLUSION}

Halal is not only a concept, but it has become a lifestyle. A halal lifestyle has become a necessity for Muslim travelers in their tourism activities. The halal tourism trend continues to grow along with the increase of Muslims traveling to all corners of the world. Some regions in Indonesia have been designated as halal tourism destinations in order to respond such a trend. The Solo City has a great opportunity as a halal tourism destination in Indonesia based on the analysis of the potential of the existing halal tourism products. In the case of Solo, the components that are worth visiting as a halal tourist destination lie in the attractions and amenities, while the accessibility and ancillary services still need serious handling if referring to the GMTI criteria (Muslim travelers' needs). If the exploitation of the four components of tourism products is maximized, the city of Solo's opportunity to be a halal tourism destination in Indonesia will be increasingly open.

\section{BIBLIOGRAPHY}

Andriani, Dini et.al. 2015. Laporan Awal Kajian Pengembangan Wisata Syariah. Jakarta: Kemenpar.

BPS Kota Surakarta. 2016. Surakarta dalam Angka 2016. Surakarta: Central Bureau of Statistics of Surakarta.

Cooper, C. 1995. Tourism: Principles and Practices. London: Longman.

Crescentrating. 2016. Mastercard and Crescentrating - Global Muslim Travel Index 2016. Accessed on 10 September 2018 from https:// newsroom.mastercard.com/asiapacific / files / 2016/03/ReportMasterCard-CrescentRating-GlobalMuslim-Travel-Index-2016.pdf

Din, K. 1989. "Islam and Tourism: Patterns, Issues, and Options". Annals of Tourism Research, 16(4), 542-563. DOI: http:/ / dx.doi.org/10.1016/01607383(89)90008-X.
Indonesian Ulama Council (MUI). 2017. What is the definition of the MUI Halal Certification, the Objectives and the Conditions. Accesed on 10 October 2018 from: http:/ / www.seputarhalal. com/apa-pengertian-sertifikasihalal-mui-tujuan-dan-syaratnya/.

Jaelani, A. 2017. Halal Tourism Industry in Indonesia: Potential and Prospects. Cirebon: Faculty of Sharia and Islamic Economic, IAIN Syekh Nurjati, MPRA Paper No. 76237.

Miles and Huberman.1992. Analisis Data Kualitatif. (penerjemah: Tjetjep Rohendi Rohidi). Jakarta: UI press.

Ministry of Tourism Republic of Indonesia. 2015. Laporan Akhir Kajian Pengembangan Wisata Syariah. Jakarta: Assistant Deputy for Research and Development of Tourism Policy, Deputy for Tourism Institution Development.

Nirwandar, S. 2016. Road to Halal Tourism and Halal Lifestyle. The paper of International Conference on Halal Tourism (ICHT 2016) in Bandung Institute of Technology, 1 September 2016.

Law of Republic of Indonesia Number 33 Year 2014 concerning on Halal Product Certification.

Pendit, Nyoman S. 2003. Ilmu Pariwisata Sebuah Pengantar Perdana. Jakarta: Pradnya Paramita.

Pitana, I Gede and Diarta, I Ketut Surya. 2009. Pengantar Ilmu Pariwisata. Yogyakarta: Penerbit Andi.

Sofyan, R. 2012. Prospek Bisnis Wisata Syariah. Jakarta: Republika.

Surakarta Tourism Office. 2018. Data Interview with staff of Surakarta Tourism Office in Developing Halal Tourism in Surakarta 2018.

Timothy, D.J.and Olsen, H. 2006. Tourism, Religion and Spiritual Journeys. Oxford: Rutledge. 
UNWTO. 2011. Religious Tourism in Asia and the Pacific. Accessed on 4 December 2017. from: http:// publications.unwto.org/:http:// publications.unwto.org/sites / all/files/pdf/110325_religious_ tourism_excerpt.pdf

Wuryasti, F. 2013. Wisata Halal, Konsep Baru Kegiatan Wisata di Indonesia. Accessed on 5 December 2017 from: http:/ / travel.detik.com/read/20
13/10/30/152010/2399509/1382/ wisata-halal-konsep-baru-kegiatanwisata-di-indonesia.

Yoeti, Oka A. 1996. Pengantar Ilmu Pariwisata. Bandung: Angkasa.

Zamani, F.H and Anderson, J.C. 2009. Islamic Tourism and Managing Tourism Development in Islamic Societies: The Cases of Iran and Saudi Arabia. International Journal of Tourism Research 12 (1). 